\title{
РОЗДІЛ 7. \\ ЕКОЛОГІЧНА БЕЗПЕКА ТА ЗБАЛАНСОВАНЕ ПРИРОДОКОРИСТУВАННЯ В АГРОПРОМИСЛОВОМУ ВИРОБНИЦТВІ
}

DOI https://doi.org/10.36059/978-966-397-240-4-20

Вінюков О. О.

доктор сільськогосподарських наук, старший дослідник, директор

Донецька державна сільськогосподарська дослідна станція Національної акадеії аграрних наук України

м. Покровськ, Донецька область

Бондарева О.Б.

кандидат технічних наук, старший науковий співробітник,

учений секретар

Донецька державна сільськогосподарська дослідна станція Національної акадеії аграрних наук України

м. Покровськ, Донецька область

\section{БІОЛОГІЗАЦІЯ ТЕХНОЛОГІЇ ВИРОЩУВАННЯ ЗЕРНОВИХ ЯК ЗАСІБ ЕКОЛОГІЗАЦІЇ ТА ПІДВИЩЕННЯ ЗЕРНОВОЇ ПРОДУКТИВНОСТІ}

Анотація. Сучасні технології вирощування зернових колосових культур спрямовані на отримання високих врожаїв зерна та екологізацію природокористування. Визначено, при комплексному застосуванні біогумусу та біостимулятора регоплант приріст урожайності зерна до контролю становив 0,66 m/га або 28,8\%, при використанні нових поживних комплексів за вирошування пшениці озимої та ячменю ярого - 1,22 m/га та 1,36 m/га на фоні внесення $\mathrm{N}_{30} \mathrm{P}_{30} K_{30}$, на органо-мінеральному фоні - 0,78 m/га та 2,08 m/га, а на органічному фоні живлення - 0,43 m/га та 1,60 m/га, що забезпечило високу економічну ефективність. Використання біодобрив у 
комплексі з біостимуляторами дозволяє до 50 \% скоротити обсяги внесення мінеральних добрив.

\section{Вступ}

Сучасне аграрне виробництво спрямоване на екологізацію природокористування на основі розширеного відтворення родючості грунту за умов дотримання безпеки довкілля і вирощеної продукції. Зростаюче значення екологізації природокористування в АПК країни і біологізації землеробства зумовлює необхідність мінімалізації витрат хіміко-техногенних ресурсів, що забезпечує зменшення антропогенного навантаження на агроекосистеми. Зменшення антропогенного навантаження на агросферу з одночасним забезпеченням оптимальної інтенсивності балансу поживних речовин може забезпечуватись впровадженням біологічних прийомів вирощування сільськогосподарських культур.

Технології вирощування зернових колосових культур спрямовані на отримання високих і стабільних врожаїв зерна та передбачають створення оптимальних умов для росту і розвитку рослин, але використання традиційних органічних добрив має вкрай низький рівень, тому практично не забезпечується повернення виносу біогенних елементів і компенсації втрат органічної речовини, що призводить до деградації грунтів і агроекосистеми взагалі.

Аналіз літературних джерел показує, що в теперішній час відбувається зміна фізико-хімічних властивостей грунту, що призводить до руйнування структури, порушення його водноповітряного і органічного складу. Вирішення проблеми керування родючістю грунту значною мірою пов'язано 3 дотриманням оптимального гумусного режиму. Для збереження в грунті бездефіцитного балансу гумусу потрібно постійне внесення органічних добрив $[1 ; 2]$.

Значна кількість досліджень спрямована на використання для відновлення родючості грунтів біогумусних органічних добрив, які одержуються промисловою переробкою компостів. Найчастіше використовують біогумус, який отримують за допомогою каліфорнійських черв'яків [3].

Концепція екологізації системи захисту повинна бути складовою частиною технології, а технологія має органічно поєднуватися 3 вимогами захисту рослин і забезпечити максимальну охорону довкілля [4]. 
Принципово нові можливості у формуванні продукційного процесу рослин ярих культур відкриває селекція нових сортів та біоінженерія. Інокуляція насіння штамами бактерій, біопрепаратами та біопротекторами відноситься до важливіших резервів подальшого підвищення рівня врожайності.

Використання препаратів азотфіксуючих і фосформобілізуючих бактерій в технологіях вирощування зернових культур в сучасних умовах можливе при розробці заходів, що дозволяють поєднувати технологічні операції: інокуляцію насіннєвого матеріалу із застосуванням мінеральних добрив [5; 6]. Дані інших авторів свідчать про доцільність застосування помірних доз мінеральних добрив, через те, що низький вміст поживних речовин у грунті зменшує рівень активності ризосферної мікрофлори [7; 8].

О.Г. Тараріко, О.В. Шерстобоєва, В.П. Патика відзначають, що вартість біопрепаратів значно нижча у порівнянні 3 вартістю добрив. Автори встановили, що використання біопрепаратів азотфіксуючих бактерій дозволяє знизити до мінімуму негативний баланс азоту в грунті і тим сприяти підвищенню рівня накопичення гумусу, що, у цілому, буде спрямовано на відновлення родючості грунтів України [9].

Встановлено [10; 11], що інокуляція насіння агрономічно цінними мікроорганізмами дозволяє рослинам задовольнятися меншою кількістю азотних і фосфорних добрив. Проте питання щодо впливу біологічних препаратів на ріст і розвиток вторинної кореневої системи рослин вивчені недостатньо, що має науковий інтерес.

Дослідження проводились на дослідному полі Донецької державної сільськогосподарської дослідної станції НААН України. Досліди закладали на спеціальних дослідних ділянках за методикою Б. О. Доспєхова [12]. Дослідження проводили у багатофакторних польових дослідах, які закладали систематичним способом. Повторність у дослідах - триразова. Площа облікової ділянки становила $80 \mathrm{~m}^{2}$.

Технологія вирощування - загальноприйнята для східної частини Північного Степу, крім поставлених на вивчення питань, та відповідала зональним і регіональним рекомендаціям.

Економічну ефективність елементів технології вирощування розраховували за типовими технологічними картами вирощування зернових культур та «Методичними рекомендаціями оперативного визначення витрат виробництва та формування цін на продукцію сільського господарства і переробної промисловості в умовах 
інфляції», які розроблені науковцями Інституту аграрної економіки НААН за цінами 2018 маркетингового року.

Енергетичну ефективність технологій вирощування оцінювали за сукупними витратами енергії, енергетичною цінністю зерна, коефіцієнтом енергетичної ефективності за методиками ДУ Інститут зернових культур НААН.

Статистична обробка, узагальнення і аналіз експериментальних результатів польових і лабораторних дослідів, а також різних спостережень і досліджень проводили за допомогою сучасних методів дисперсійного та кореляційного аналізів на ПК.

\section{1. Вплив нових поживних комплексів на ріст і розвиток рослин пшениці озимої}

Використання біопрепаратів створює реальні передумови для суттєвого підвищення врожаю зернових культур 3 одночасним зменшенням на 25-30\% норм внесення мінеральних добрив [13; 14]. Запобігти цьому можна шляхом пошуку та широкого впровадження у виробництво біологічних систем живлення та захисту рослин, а вивчення ефективності новітніх поживних комплексів та активне залучення їх у виробничий процес має великий науковий та практичний інтерес.

Досліджувались поживні комплекси створенні з урахуванням найнеобхідніших елементів живлення рослин пшениці озимої, які додатково живлять рослини в основні критичні періоди вегетації та фази розвитку, а саме - проростання насіння, фази кущіння та колосіння. Також схема досліду передбачала вивчення хімічного та біологічного захисту посівів. Хімічний захист посівів здійснювався через протруєння насіння Вітавакс 200ФФ (3 л/т) та обприскування посівів інсектицидом Борей (0,1 л/га) і фунгіцидом Фалькон (0,6 л/га), біологічний - через інокуляцію насіння мікробіологічним комплексом (400 г/т).

За різних фонів живлення та поживних комплексів, які використовувалися в досліді, глибина залягання вузла кущіння рослин пшениці озимої на час припинення осінньої вегетації суттєво варіювала (табл. 1).

На мінеральному фоні живлення найбільше заглиблення вузла кущіння $(4,8$ см) було відмічене на варіанті застосування хімічного захисту (на контролі вузол кущіння знаходився на 0,9 см ближче до поверхні, відносно варіанту з хімічним захистом). Найменшу глибину залягання вузла кущіння відмічали при використанні другого поживного комплексу: на 1,4 см вище ніж за хімічного захисту посівів та на 0,5 см - порівняно з контрольним варіантом. 
Таблиця 1

\section{Стан рослин пшениці озимої сорту Краплина на час припинення осінньої вегетації (середнє за 2015-2018 рр.)}

\begin{tabular}{|c|c|c|c|c|c|}
\hline 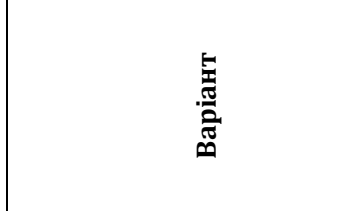 & 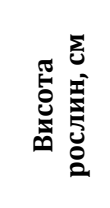 & 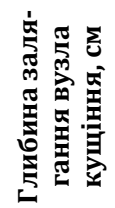 & 氞 & 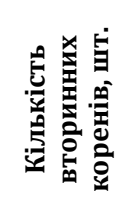 & 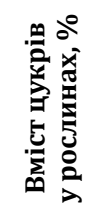 \\
\hline \multicolumn{6}{|c|}{ Фон $1-\mathrm{N}_{30} \mathrm{P}_{30} \mathrm{~K}_{30}$} \\
\hline Контроль & 17,1 & 3,9 & 1,1 & 0,5 & 30,01 \\
\hline Хімічний захист посівів & 15,6 & 4,8 & 1,4 & 0,9 & 40,54 \\
\hline Біологічний захист посівів & 15,5 & 3,6 & 1,3 & 0,3 & 32,58 \\
\hline Комплекс $1^{*}$ & 12,7 & 3,9 & 1,3 & 0,5 & 35,72 \\
\hline Комплекс $2^{* *}$ & 12,2 & 3,4 & 1,2 & 0,7 & 33,47 \\
\hline Комплекс $3^{* * *}$ & 14,8 & 3,8 & 1,5 & 1,2 & 40,62 \\
\hline $\mathrm{HIP}_{05}$ & $0,1-0,6$ & $0,3-0,9$ & $0,02-0,05$ & $0,01-0,03$ & $1,3-2,1$ \\
\hline \multicolumn{6}{|c|}{ Фон $2-\mathrm{N}_{15} \mathrm{P}_{15} \mathrm{~K}_{15}+$ біогумус (250 кг/га) } \\
\hline Контроль & 14,7 & 4,4 & 1,3 & 0 & 34,08 \\
\hline Хімічний захист посівів & 15,0 & 4,9 & 1,8 & 0,8 & 42,49 \\
\hline Біологічний захист посівів & 12,0 & 3,4 & 1,2 & 0,9 & 24,17 \\
\hline Комплекс $1^{*}$ & 12,3 & 3,5 & 1,9 & 1,0 & 30,23 \\
\hline Комплекс $2^{* *}$ & 12,3 & 3,3 & 2,0 & 1,0 & 32,78 \\
\hline Комплекс $3^{* * *}$ & 13,7 & 3,3 & 2,1 & 1,4 & 33,42 \\
\hline $\mathrm{HIP}_{05}$ & $0,4-0,7$ & $0,1-0,3$ & $0,09-0,10$ & $0,01-0,05$ & $1,0-1,3$ \\
\hline \multicolumn{6}{|c|}{ Фон 3 - біогумус (250 кг/га) } \\
\hline Контроль & 15,1 & 4,9 & 1,0 & 0,1 & 32,93 \\
\hline Хімічний захист посівів & 16,8 & 5,1 & 1,2 & 0,8 & 42,59 \\
\hline Біологічний захист посівів & 13,1 & 4,4 & 1,0 & 0,6 & 33,26 \\
\hline Комплекс $1^{*}$ & 13,0 & 4,6 & 1,2 & 0,9 & 24,38 \\
\hline Комплекс $2^{* *}$ & 13,0 & 4,2 & 1,1 & 0,8 & 25,01 \\
\hline Комплекс $3^{* * *}$ & 13,8 & 4,6 & 1,4 & 1,1 & 26,47 \\
\hline $\begin{array}{l}\text { НІР } 05 \text { для: } \\
\text { варіанту досліду }\end{array}$ & $0,5-0,6$ & $0,1-0,4$ & $0,01-0,03$ & $0,02-0,04$ & $1,3-1,6$ \\
\hline фону живлення & $0,1-0,3$ & $0,3-0,5$ & $0,01-0,02$ & $0,06-0,08$ & $0,9-1,1$ \\
\hline взаємодії & $0,8-0,9$ & $0,6-0,7$ & $0,04-0,05$ & $0,11-0,12$ & $1,9-2,1$ \\
\hline
\end{tabular}

Примітка: *Обробка насіння препаратом Rost-Forte (0,5 л/га) у суміші 3 комплексом амінокислот, обприскування рослин у фазах кущіння та колосіння сумішшю препаратів Rost-концентрат 15.7.7. (1 л/га) + комплекс амінокислот + Хелатин (2 л/га)+ мікробіологічний комплекс (400 г/га).

${ }^{* *}$ Обробка насіння препаратом Айдар (1 л/т), обприскування рослин у фазах кущіння та колосіння сумішшю препарат Айдар (2 л/га) та мікробіологічний комплекс (400 г/га).

${ }^{* * *}$ Обробка насіння препаратом Сизам (250 г/т) у суміші з мікробіологічним комплексом, обприскування рослин у фазі кущіння сумішшю препарат Сизам (250 г/га) та мікробіологічний комплекс (400 г/га). 
Подібна закономірність заглиблення вузла кущіння порівняно 3 іншими варіантами на контролі та хімічному захисту посівів простежувалася й на інших фонах живлення. Однак наймілкіше залягання вузла кущіння відносно всіх варіантів було при використанні комплексів 2 та 3 на органо-мінеральному фоні живлення (3,3 см).

Коефіцієнт кущіння та кількість вторинних коренів суттєво відрізнялися між варіантами відносно фонів живлення, однак найвищими вони були при використанні поживного комплексу 3 незалежно від фону живлення. Так, на мінеральному фоні ці показники перевищили контроль на 0,4 та 0,7 шт.; на органомінеральному фоні - на 0,8 та 1,4 шт.; на органічному фоні живлення - на 0,4 та 1,0 шт., відповідно.

Порівнюючи розвиток рослин пшениці озимої залежно від фону живлення було встановлено, що на час припинення осінньої вегетації найкращі біометричні показники мали рослини, де використовувався органо-мінеральний фон живлення.

Що стосується вмісту цукрів у рослинах, то незалежно від фону живлення та обробок кількість вуглеводів була достатньою для доброї перезимівлі рослин, але найбільшою вона була при використанні хімічного захисту посівів пшениці озимої.

Наприкінці фази кущіння проводився відбір рослин для біометричного аналізу. Виявлено, що на мінеральному фоні живлення найбільший приріст значень показників рослин відносно контролю було при використанні поживного комплексу 3 (табл. 2). Так, коефіцієнт кущіння перевищив контрольний варіант на 0,3, а кількість вторинних коренів - на 1,1 шт.

На органо-мінеральному фоні живлення найбільш істотне підвищення коефіцієнта кущіння порівняно з контролем було отримано при використанні комплексів 1 та 3. Так, цей показник збільшився на 0,3 та 0,5, відповідно.

Кількість вторинних коренів була вищою за контрольний варіант на 1,0 шт. при використанні поживного комплексу 3.

На органічному фоні живлення були отримані більш вирівняні рослини за розвитком. Так, при використанні хімічного захисту посівів, комплексу 2 та комплексу 3 отримано однакові коефіцієнти кущіння $(2,8)$. На цих же варіантах найбільшою була і кількість вторинних коренів - 1,6 шт.; 1,7шт. та 1,8шт., відповідно.

Рослини у варіантах досліду, де використовували поживний комплекс 1 та біологічний захист посівів, сформували кількість 
вторинних коренів, яка була нижчою за контроль на 0,2 шт. та 0,5 шт. відповідно.

Таблиця 2

Стан рослин пшениці озимої сорту Краплина наприкінці фази кущіння (середнє за 2015-2018 рр.)

\begin{tabular}{|l|c|c|c|}
\hline \multicolumn{1}{|c|}{ Варіант } & $\begin{array}{c}\text { Висота } \\
\text { рослин, см }\end{array}$ & $\begin{array}{c}\text { Коефіцієнт } \\
\text { кущіння }\end{array}$ & $\begin{array}{c}\text { Коефіцієнт } \\
\text { вторинних } \\
\text { коренів }\end{array}$ \\
\hline \multicolumn{3}{|c|}{ Фон $1-\mathrm{N}_{30} \mathrm{P}_{30} \mathrm{~K}_{30}$} \\
\hline Контроль & 41,4 & 3 & 4 \\
\hline Хімічний захист посівів & 45,2 & 3,9 & 2,3 \\
\hline Біологічний захист посівів & 41,3 & 3,2 & 2,6 \\
\hline Комплекс 1 & 38,7 & 3,6 & 2,4 \\
\hline Комплекс 2** & 40,8 & 3,3 & 2,0 \\
\hline Комплекс 3 ${ }^{* * *}$ & 43,6 & 2,8 & 2,0 \\
\hline
\end{tabular}

Закінчення таблиці 2

\begin{tabular}{|l|c|c|c|}
\hline \multicolumn{1}{|c|}{1} & 2 & 3 & 4 \\
\hline \multicolumn{1}{|c|}{ Фон 2- ${ }_{15} \mathrm{P}_{15} \mathrm{~K}_{15}+$ біогумус $(250$ кг/га) } \\
\hline Контроль & 40,8 & 3,3 & 1,9 \\
\hline Хімічний захист посівів & 39,8 & 3,2 & 1,7 \\
\hline Біологічний захист посівів & 37,5 & 3,2 & 2,0 \\
\hline Комплекс 1* & 39,0 & 3,6 & 2,1 \\
\hline Комплекс 2** & 40,6 & 3,4 & 2,4 \\
\hline Комплекс 3*** & 41,3 & 3,8 & 2,9 \\
\hline \multicolumn{4}{|c|}{ Фон 3 - біогумус $(250$ кг/га) } \\
\hline Контроль & 43,8 & 3,0 & 1,5 \\
\hline Хімічний захист посівів & 38,9 & 2,8 & 1,6 \\
\hline Біологічний захист посівів & 35,2 & 2,0 & 1,0 \\
\hline Комплекс 1* & 37,0 & 2,4 & 1,3 \\
\hline Комплекс 2** & 41,5 & 2,8 & 1,7 \\
\hline Комплекс 3*** & 38,2 & 2,8 & 1,8 \\
\hline
\end{tabular}

При порівнянні трьох фонів живлення між собою було встановлено, що на формування біометричних показників найбільше вплинули мінеральний та органо-мінеральний фони живлення (табл. 3).

Жоден із представлених варіантів не забезпечив достовірного збільшення коефіцієнта загального кущіння порівняно 3 контролем на мінеральному фоні живлення, окрім хімічного та біологічного захисту посівів. 
Таблиця 3

Біометричні показники рослин пшениці озимої сорту

Краплина на початку фази колосіння

(середнє за 2015-2018 рр.)

\begin{tabular}{|c|c|c|c|c|c|}
\hline \multirow[b]{2}{*}{ Варіант } & \multirow{2}{*}{ 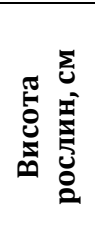 } & \multicolumn{2}{|c|}{$\begin{array}{c}\text { Кількість } \\
\text { стебел, шт./м² }\end{array}$} & \multicolumn{2}{|c|}{$\begin{array}{c}\text { Коефіцієнт } \\
\text { кущіння }\end{array}$} \\
\hline & & 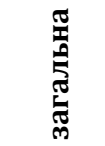 & 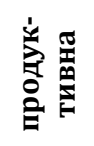 & 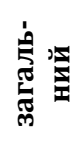 & 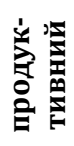 \\
\hline \multicolumn{6}{|c|}{ Фон $1-\mathrm{N}_{30} \mathrm{P}_{30} \mathrm{~K}_{30}$} \\
\hline Контроль & 56,2 & 565,5 & 477,5 & 1,73 & 1,46 \\
\hline Хімічний захист посівів & 70,0 & 555,5 & 464,0 & 2,07 & 1,72 \\
\hline Біологічний захист посівів & 69,6 & 572,0 & 451,0 & 1,76 & 1,39 \\
\hline Комплекс $1^{*}$ & 71,1 & 570,5 & 473,5 & 1,71 & 1,42 \\
\hline Комплекс $2^{* *}$ & 70,4 & 618,0 & 487,0 & 1,73 & 1,36 \\
\hline Комплекс $3^{* * *}$ & 69,4 & 645,5 & 540,0 & 1,72 & 1,44 \\
\hline \multicolumn{6}{|c|}{ Фон $2-\mathrm{N}_{15} \mathrm{P}_{15} \mathrm{~K}_{15}+$ біогумус (250 кг/га) } \\
\hline Контроль & 67,5 & 543,0 & 431,0 & 1,72 & 1,37 \\
\hline Хімічний захист посівів & 69,8 & 545,0 & 489,0 & 1,97 & 1,55 \\
\hline Біологічний захист посівів & 68,7 & 555,0 & 424,0 & 1,89 & 1,44 \\
\hline Комплекс $1^{*}$ & 70,0 & 616,0 & 487,5 & 1,94 & 1,53 \\
\hline Комплекс $2^{* *}$ & 69,2 & 657,5 & 520,0 & 2,13 & 1,68 \\
\hline Комплекс $3^{* * *}$ & 69,2 & 596,0 & 456,0 & 1,84 & 1,41 \\
\hline \multicolumn{6}{|c|}{ Фон 3 - біогумус (250 кг/га) } \\
\hline Контроль & 66,7 & 541,0 & 424,0 & 1,83 & 1,44 \\
\hline Хімічний захист посівів & 69,8 & 508,0 & 432,0 & 1,85 & 1,58 \\
\hline Біологічний захист посівів & 69,2 & 568,5 & 425,0 & 1,67 & 1,25 \\
\hline Комплекс $1^{*}$ & 68,0 & 558,0 & 443,5 & 1,77 & 1,40 \\
\hline Комплекс $2^{* *}$ & 69,0 & 584,0 & 469,0 & 1,62 & 1,30 \\
\hline Комплекс $3^{* * *}$ & 68,2 & 570,0 & 427,5 & 1,86 & 1,39 \\
\hline
\end{tabular}

При застосуванні органо-мінерального фону живлення у всіх варіантах коефіцієнти загального та продуктивного кущіння були вищими за контрольний варіант, але найкращими ці показники були за використання комплексу 2 (2,13 та 1,68, відповідно, що на 0,41 та на 0,31 вище за контроль). На органічному фоні живлення лише один варіант перевищив контроль за коефіцієнтом загального кущіння комплекс $3(+0,03)$, а за коефіцієнтом продуктивного кущіння варіант із хімічним захистом посівів $(+0,14)$.

При порівнянні трьох фонів живлення, можна зробити висновок, що найбільший ефект від поживних комплексів було отримано при вико- 
ристанні органо-мінерального фону. Тобто, на органо-мінеральному фоні живлення були отримані коефіцієнти загального та продуктивного кущіння, які суттєво перевищили контрольний варіант.

При вивченні впливу застосування агротехнічних заходів вирощування, передбачених різними варіантами досліду на показники структури врожайності пшениці озимої, було встановлено, що на мінеральному та органо-мінеральному фонах живлення (комплекс 3), було досягнуто поліпшення елементів структури врожайності відносно контролю щодо всіх показників. Довжина колосу збільшилась порівняно з контролем на 1,5 та 1,1 см; кількість зерен у колосі - на 0,9 та 2,0 шт., а маса 1000 зерен - на 3,02 та 1,15 г, відповідно (табл. 4).

Таблиця 4

Показники структури врожайності пшениці озимої сорту Краплина (середнє за 2015-2018 рр.)

\begin{tabular}{|c|c|c|c|c|}
\hline Варіант & $\begin{array}{c}\text { Дов- } \\
\text { жина } \\
\text { колосу, } \\
\text { см }\end{array}$ & \begin{tabular}{|c|} 
Кількість \\
зерен \\
у колосі, \\
шт.
\end{tabular} & $\begin{array}{c}\text { Маса } \\
1000 \\
\text { зерен, г }\end{array}$ & $\begin{array}{c}\text { Натура } \\
\text { зерна, } \\
\text { г/л }\end{array}$ \\
\hline 1 & 2 & 3 & 4 & 5 \\
\hline \multicolumn{5}{|c|}{$\Phi_{\mathrm{OH}} 1-\mathrm{N}_{30} \mathrm{P}_{30} \mathrm{~K}_{30}$} \\
\hline Контроль & 8,3 & 27,0 & 35,21 & 691,3 \\
\hline Хімічний захист посівів & 8,9 & 27,5 & 37,62 & 721,1 \\
\hline Біологічний захист посівів & 8,5 & 27,3 & 37,20 & 719,0 \\
\hline Комплекс $1^{*}$ & 9,2 & 27,8 & 38,06 & 728,3 \\
\hline Комплекс $2^{* *}$ & 9,4 & 27,7 & 37,88 & 743,4 \\
\hline Комплекс $3^{* * *}$ & 9,8 & 27,9 & 38,23 & 751,4 \\
\hline $\mathrm{HIP}_{0,5}$ & $0,03-0,10$ & $0,05-0,12$ & $0,5-1,4$ & $1,7-2,4$ \\
\hline \multicolumn{5}{|c|}{ Фон $2-\mathrm{N}_{15} \mathrm{P}_{15} \mathrm{~K}_{15}+$ біогумус $(250$ кг $/$ га) } \\
\hline Контроль & 8,0 & 26,4 & 40,08 & 701,1 \\
\hline Хімічний захист посівів & 7,9 & 27,4 & 33,88 & 724,4 \\
\hline Біологічний захист посівів & 8,4 & 27,5 & 41,34 & 736,1 \\
\hline Комплекс $1^{*}$ & 8,4 & 27,8 & 33,35 & 728,3 \\
\hline Комплекс $2^{* *}$ & 8,3 & 28,0 & 34,07 & 730,5 \\
\hline Комплекс $3^{* * *}$ & 9,1 & 28,4 & 41,23 & 745,6 \\
\hline $\mathrm{HIP}_{0,5}$ & $0,02-0,09$ & $0,1-0,4$ & $0,01-0,07$ & $1,5-2,2$ \\
\hline \multicolumn{5}{|c|}{ Фон 3 - біогумус (250 кг/га) } \\
\hline Контроль & 7,5 & 26,2 & 38,62 & 686,6 \\
\hline Хімічний захист посівів & 7,8 & 26,4 & 37,09 & 698,4 \\
\hline Біологічний захист посівів & 8,0 & 26,7 & 37,28 & 683,1 \\
\hline
\end{tabular}


Закінчення таблиці 4

\begin{tabular}{|l|c|c|c|c|}
\hline \multicolumn{1}{|c|}{1} & 2 & 3 & 4 & 5 \\
\hline Комплекс 1* $^{*}$ & 8,3 & 26,8 & 37,02 & 700,2 \\
\hline Комплекс 2** & 8,5 & 26,6 & 34,87 & 705,7 \\
\hline Комплекс 3** & 8,5 & 27,1 & 40,74 & 711,4 \\
\hline НІР 05 для: варіанту досліду & $0,1-0,2$ & $0,1-0,2$ & $2,12-2,18$ & $4,4-5,1$ \\
\hline фону живлення & $0,1-0,2$ & $0,1-0,3$ & $2,28-2,34$ & $6,3-6,7$ \\
\hline взаємодії & $0,2-0,3$ & $0,2-0,4$ & $2,62-2,74$ & $8,1-8,3$ \\
\hline
\end{tabular}

На органічному фоні живлення найдовше колосся (8,5 см) було при використанні поживних комплексів 2 та 3, що перевищило контрольний варіант на 1,0 см. Кількість зерен у колосі та натура зерна більшими були при застосуванні комплексу 3 (+0,9 та +24,8 г/л, відповідно). Найбільша маса 1000 зерен була отримана у варіанті $з$ використанням поживного комплексу 3 (+2,12 г відносно контролю).

При порівнянні впливу фонів живлення на показники структури врожайності було встановлено, що мінеральний фон живлення сприяв збільшенню довжини колоса, маси 1000 зерен та натури зерна, а органо-мінеральний фон забезпечив найбільшу озерненість колоса.

У таблиці 5 представлена залежність рівня врожайності зерна пшениці озимої від запропонованих поживних комплексів відповідно фону живлення.

На мінеральному фоні живлення, в середньому за роки проведення досліджень, використання комплексу 3 забезпечило найвищу прибавку врожайності порівняно з контролем $(1,22$ т/га, або 48,0 \%). Найменший приріст врожайності був при застосуванні біологічного захисту посівів (0,04 т/га, або 1,6 \%).

На органо-мінеральному фоні живлення також продуктивнішими були рослини, оброблені комплексом 3 (+0,78 т/га, або 30,5 \% порівняно з контролем). Проте, не у всіх варіантів цього фону живлення відзначена достовірна прибавка врожайності зерна до контролю. Так, застосування хімічного захисту посівів та комплексу 1 сприяло зниженню рівня зернової продуктивності порівняно 3 контролем на 0,02 т/га (-0,78\%) та 0,04 т/га (-1,56 \%), відповідно.

На органічному фоні живлення всі запропоновані поживні комплекси сприяли прибавці врожайності зерна. Істотніше підвищення рівня зернової продуктивності відносно контролю забезпечив комплекс 3 (+0,43 т/га, або 18,8 \%). Найменшою прибавка $(0,06$ т/га до контролю) була при використанні комплексу 2. 
Таблиця 5

Урожайність зерна пшениці озимої (середнє за 2015-2018 рр.)

\begin{tabular}{|c|c|c|c|}
\hline \multirow{2}{*}{ Варіант } & \multirow{2}{*}{$\begin{array}{c}\text { Урожайність } \\
\text { зерна, т/га }\end{array}$} & \multicolumn{2}{|c|}{ Прибавка } \\
\hline & & т/га & $\%$ \\
\hline \multicolumn{4}{|c|}{ ФоH $1-\mathrm{N}_{30} \mathrm{P}_{30} \mathrm{~K}_{30}$} \\
\hline Контроль & 4,54 & - & - \\
\hline Хімічний захист посівів & 4,80 & 0,26 & 10,2 \\
\hline Біологічний захист посівів & 4,58 & 0,04 & 1,6 \\
\hline Комплекс $1^{*}$ & 5,01 & 0,47 & 18,5 \\
\hline Комплекс $2^{* *}$ & 5,11 & 0,57 & 22,4 \\
\hline Комплекс $3^{* * *}$ & 5,76 & 1,22 & 48,0 \\
\hline \multicolumn{4}{|c|}{ Фон $2-\mathrm{N}_{15} \mathrm{P}_{15} \mathrm{~K}_{15}+$ біогумус $(250$ кг $/$ га) } \\
\hline Контроль & 4,56 & - & - \\
\hline Хімічний захист посівів & 4,54 & $-0,02$ & $-0,78$ \\
\hline Біологічний захист посівів & 4,82 & 0,26 & 10,2 \\
\hline Комплекс $1^{*}$ & 4,52 & $-0,04$ & $-1,56$ \\
\hline Комплекс $2^{* *}$ & 4,96 & 0,40 & 15,6 \\
\hline Комплекс $3^{* * *}$ & 5,34 & 0,78 & 30,5 \\
\hline \multicolumn{4}{|c|}{ Фон 3 - біогумус (250 кг /га) } \\
\hline Контроль & 4,29 & - & - \\
\hline Хімічний захист посівів & 4,23 & $-0,06$ & $-2,6$ \\
\hline Біологічний захист посівів & 4,23 & $-0,06$ & $-2,6$ \\
\hline Комплекс $1^{*}$ & 4,40 & 0,11 & 4,8 \\
\hline Комплекс $2^{* *}$ & 4,35 & 0,06 & 2,6 \\
\hline Комплекс $3^{* * *}$ & 4,72 & 0,43 & 18,8 \\
\hline
\end{tabular}

Взагалі рівень урожайності зерна залежав більшою мірою від фону живлення, зокрема на мінеральному фоні рослинами пшениці озимої був сформований найвищий рівень урожайності і дещо нижчий на органо-мінеральному фоні. Хоча в цілому ступінь розвитку рослин протягом вегетації та формування рослинами врожайності зерна при використанні запропонованих поживних комплексів свідчить про правильність вибраного напряму досліджень.

Розрахунок економічної ефективності (табл. 6) вирощування пшениці озимої підтверджує, що незалежно від фону живлення застосування запропонованих елементів доцільне при вирощуванні даної культури. 
Таблиця 6

\section{Економічна та біоенергетична ефективність вирощування пшениці озимої залежно від фону живлення та поживного комплексу (2011-2018 рр.)}

\begin{tabular}{|c|c|c|c|c|c|c|}
\hline \multirow[b]{2}{*}{ Показники } & \multicolumn{6}{|c|}{ Варіанти досліду } \\
\hline & $\begin{array}{c}\text { Конт- } \\
\text { роль }\end{array}$ & \begin{tabular}{|c|} 
Хіміч- \\
Ний \\
захист \\
посівів \\
\end{tabular} & \begin{tabular}{|c|} 
Біоло- \\
гічний \\
захист \\
посівів
\end{tabular} & $\begin{array}{l}\text { Комп- } \\
\text { лекс 1 }\end{array}$ & $\begin{array}{l}\text { Комп- } \\
\text { лекс } 2\end{array}$ & $\begin{array}{l}\text { Комп- } \\
\text { лекс } 3\end{array}$ \\
\hline \multicolumn{7}{|c|}{ ФоH $-\mathrm{N}_{30} \mathrm{P}_{30} \mathrm{~K}_{30}$} \\
\hline Урожайність, т/га & 4,54 & 4,80 & 4,58 & 5,01 & 5,11 & 5,76 \\
\hline Виробничі витрати, грн/га & 8504 & 9739 & 8626 & 10135 & 9907 & 9892 \\
\hline Собівартість 1 т зерна, грн & 1873 & 2029 & 1883 & 2023 & 1939 & 1717 \\
\hline Чистий дохід, грн: на 1 га & 11737 & 11861 & 11984 & 12410 & 13088 & 16028 \\
\hline на 1 т & 2585 & 2471 & 2617 & 2477 & 2561 & 2783 \\
\hline Рівень рентабельності, \% & 138,0 & 121,8 & 138,9 & 122,5 & 132,1 & 162,0 \\
\hline Затрати сукупної енергії, МДж/га & 12474 & 12970 & 12560 & 14830 & 14486 & 13930 \\
\hline Енергоємкість 1 т зерна, МДж & 2748 & 2702 & 2742 & 2960 & 2835 & 2418 \\
\hline $\begin{array}{l}\text { Коефіцієнт енергетичної } \\
\text { ефективності }\end{array}$ & 5,99 & 6,09 & 6,00 & 5,56 & 5,80 & 6,80 \\
\hline \multicolumn{7}{|c|}{ Фон $-\mathrm{N}_{15} \mathrm{P}_{15} \mathrm{~K}_{15}+$ біогумус (250 кг /га) } \\
\hline Урожайність, т/га & 4,56 & 4,54 & 4,82 & 4,52 & 4,96 & 5,34 \\
\hline Виробничі витрати, грн/га & 8479 & 9558 & 8724 & 9826 & 9788 & 9623 \\
\hline Собівартість 1 т зерна, грн & 1860 & 2105 & 1810 & 2174 & 1973 & 1802 \\
\hline Чистий дохід, грн: на 1 га & 11851 & 10872 & 12966 & 10514 & 12532 & 14407 \\
\hline на 1 т & 2599 & 2395 & 2690 & 2326 & 2527 & 2698 \\
\hline Рівень рентабельності, \% & 139,8 & 113,7 & 148,6 & 107,0 & 128,0 & 149,7 \\
\hline Затрати сукупної енергії, МДж/га & 12167 & 12429 & 12435 & 14098 & 14036 & 13257 \\
\hline Енергоємкість 1 т зерна, МДж & 2668 & 2738 & 2580 & 3119 & 2830 & 2483 \\
\hline $\begin{array}{l}\text { Коефіцієнт енергетичної } \\
\text { ефективності }\end{array}$ & 6,17 & 6,01 & 6,38 & 5,27 & 5,81 & 6,63 \\
\hline \multicolumn{7}{|c|}{ Фон - Біогумус (250 кг/га) } \\
\hline Урожайність, т/га & 4,29 & 4,23 & 4,23 & 4,40 & 4,35 & 4,72 \\
\hline Виробничі витрати, грн/га & 7438 & 8495 & 7505 & 8869 & 8557 & 8387 \\
\hline Собівартість 1 т зерна, грн & 1734 & 2008 & 1774 & 2016 & 1967 & 1777 \\
\hline Чистий дохід, грн: на 1 га & 10794 & 10364 & 11354 & 10748 & 10837 & 12656 \\
\hline на 1 т & 2516 & 2450 & 2684 & 2443 & 2491 & 2681 \\
\hline Рівень рентабельності, \% & 145,1 & 122,0 & 151,3 & 121,2 & 126,6 & 150,9 \\
\hline Затрати сукупної енергії, МДж/га & 11104 & 11333 & 11106 & 13160 & 12691 & 11903 \\
\hline Енергоємкість 1 т зерна, МДж & 2588 & 2679 & 2626 & 2991 & 2917 & 2522 \\
\hline $\begin{array}{l}\text { Коефіцієнт енергетичної } \\
\text { ефективності }\end{array}$ & 6,36 & 6,14 & 6,27 & 5,50 & 5,64 & 6,52 \\
\hline
\end{tabular}


Найкращі показники серед представлених варіантів, незалежно від фону живлення, забезпечив поживний комплекс 3.

Серед фонів живлення найбільш ефективними виявились мінеральний та органо-мінеральний забезпечивши рівень рентабельності вищий за контроль від 9,9 \% (органо-мінеральний фон) до $24 \%$ (мінеральний фон). Органічний фон живлення через низький рівень продуктивності рослин мав найнижчі економічні показники: собівартість 1 т зерна склала 1734 грн, а найвищий рівень рентабельності $150,9 \%$, що лише на $5,8 \%$ вище за контрольний варіант. Проте, якщо б продукція рослинництва, отримана за використання елементів органічної технології вирощування, мала статус органічної продукції та відповідну ціну, то показники економічної ефективності виглядали б зовсім по іншому.

Найнижчі затрати сукупної енергії, при порівнянні фонів живлення, були при використанні органічного фону. Що стосовно поживних комплексів, які вивчались, то найменші затрати сукупної енергії було отримано при використанні комплексу 3. Так, на мінеральному фоні живлення затрати сукупної енергії склали 13930 МДж, на органо-мінеральному - 13257 МДж, на органічному фоні живлення - 11903 МДж.

Найвищі коефіцієнти енергетичної ефективності були отримані при застосуванні також поживного комплексу 3: на мінеральному фоні живлення - 6,80; на органо-мінеральному фоні живлення 6,63; на органічному - 6,52.

Розрахунок економічної та біоенергетичної ефективності використання нових поживних комплексів на різних фонах живлення переконливо свідчить про значну перевагу запропонованих елементів над контрольним варіантом. Залежно від фону живлення ефективність застосування поживних комплексів була різною. Найвищі показники були отримані на органо-мінеральному фоні. Поєднання поживних комплексів 3 органо-мінеральним фоном дозволяє знизити матеріальні витрати на вирощування пшениці озимої 3 одночасним підвищенням рівня рентабельності виробництва продукції.

\section{2. Вплив внесення органічних добрив та біостимуляторів росту на ріст і розвиток рослин ячменю ярого}

Гострий дефіцит традиційних органічних добрив можна компенсувати залученням поновлюваних джерел в енергетичний баланс 
аграрної галузі. Безперервна потреба у високоякісних органічних добривах може бути забезпечена шляхом утилізації біомаси. Переробка біомаси (органічних сільськогосподарських відходів) метановим бродінням дає змогу отримувати біогаз, що містить близько 70 \% метану і знезаражені органічні добрива. Біодобрива, що отримані при бродінні в біогазових установках без підстилкової гнойової біомаси ВРХ, за своїми фізико-хімічними та токсичними показниками можуть бути використаними у біологічному землеробстві. Використання біогумусу забезпечує більш повне використання біологічних факторів, високий рівень рециркуляції біогенних елементів, покращення екологічного стану територій.

Важливим елементом сучасних ресурсозберігаючих технологій вирощування сільськогосподарських культур $є$ застосування нових видів біостимуляторів, які підвищують ефективність використання мінеральних добрив, покращуючи умови живлення рослин та їх урожайність. Використання цих препаратів дозволяє значно скоротити обсяги внесення традиційних мінеральних добрив, що зменшує втрати елементів живлення рослин та унеможливлює забруднення навколишнього середовища.

По варіантах досліду під передпосівну культивацію внесений біогумус із біогазової установки по переробці свинячого гною (Біогумус-1) i гранульований біогумус, що одержано при біотехнологічній переробці осаду стічних вод вермикомпостуванням (Біогумус-2). Норма внесення Біогумусу-1 (вміст органічної речовини (91-94\%), а також поживних речовин азот загальний 1,8-2,0 \%, фосфор загальний - 1,5-1,8 \%, калій загальний 0,3-0,6\%)) становила 500 кг/га, Біогумус-2 (вміст органічної речовини в перерахунку на вуглець - $12,34 \%$; масова частка азоту $1,08 \%$; фосфору - 1,64; калію - 1,21\%) було внесено нормою 250 кг/га. Біогумус обох видів вносили кожний окремо і разом 3 мінеральними добривами в дозі $\mathrm{N}_{30} \mathrm{P}_{30} \mathrm{~K}_{30}$ i $\mathrm{N}_{15} \mathrm{P}_{15} \mathrm{~K}_{15}$.

Схема досліду також включала обприскування посівів у фазі кущіння біостимуляторами Регоплант (50 мл/га) і Стимпо (20 мл/га).

Регулятор росту Стимпо - новітній композиційний препарат біологічного походження, в основу дії якого покладено синергічний ефект взаємодії продуктів біотехнологічного культивування грибів-мікроміцетів 3 кореневої системи женьшеню і продуктів життєдіяльності бактерій Streptomyces Avermetilis - аверсектину. До складу препарату входять ненасичені кислоти С11-C28, вуглеводи (глюкоза, рибоза, галактоза), близько 15 амінокислот, 
мікроелементи - іони $\mathrm{K}, \mathrm{Mn}, \mathrm{Mg}, \mathrm{Fe}, \mathrm{Cu}$, аналоги натуральних фітогормонів типу цитокініну і ауксин, біогенні мікроелементи, поліненасичені жирні кислоти, відповідальні за утворення фітонцидів і фітоалексинів, а також аверсектін.

Регоплант - біостимулятор рослин із серії композиційних препаратів, у основу дії якого покладено синергічний ефект взаємодії продуктів біотехнологічного культивування грибівмікроміцетів 3 кореневої системи женьшеню і аверсектину. Збалансована композиція біологічно активних сполук-аналогів фітогормонів, амінокислот, жирних кислот, олігосахаридів, хітозану і мікроелементів, а також біозахистних з'єднань.

Результати фенологічних спостережень свідчать про позитивний вплив заходів, що досліджувались, на ріст та розвиток рослин. У фазі кущіння проводився біометричний аналіз рослин на даному етапі (табл. 7).

На посівах ячменю ярого при застосуванні тільки біогумусу обох видів висота рослин була нижчою за варіант, де використовувалися мінеральні добрива (+7,0 см до контролю), але була більшою за контрольний варіант на 3,3-3,6 см. При сумісному використанні біогумусу та $\mathrm{N}_{15} \mathrm{P}_{15} \mathrm{~K}_{15}$ рослини були вищими за контрольний варіант на 5,1-5,3 см.

Таблиця 7

Біометричні показники рослин ячменю ярого сорту Аверс у фазі кущіння (середнє за 2011-2015 рр.)

\begin{tabular}{|c|c|c|c|}
\hline Варіант досліду & $\begin{array}{c}\text { Висота } \\
\text { рослин, см }\end{array}$ & $\begin{array}{c}\text { Кількість } \\
\text { стебел, шт./м² }\end{array}$ & $\begin{array}{c}\text { Коеф. } \\
\text { кущіння }\end{array}$ \\
\hline Контроль - без добрив & 34,5 & 860 & 1,86 \\
\hline $\mathrm{N}_{30} \mathrm{P}_{30} \mathrm{~K}_{30}$ & 41,5 & 1210 & 2,75 \\
\hline Біогумус-1 & 38,1 & 965 & 2,18 \\
\hline Біогумус-2 & 37,8 & 945 & 2,19 \\
\hline Біогумус- $1+\mathrm{N}_{15} \mathrm{P}_{15} \mathrm{~K}_{15}$ & 39,6 & 1168 & 2,66 \\
\hline Біогумус- $2+\mathrm{N}_{15} \mathrm{P}_{15} \mathrm{~K}_{15}$ & 39,8 & 1150 & 2,68 \\
\hline
\end{tabular}

Найбільший коефіцієнт кущіння ячменю ярого $(2,75)$ отримали за мінерального фону живлення. Застосування біогумусу 3 половинною нормою мінеральних добрив забезпечило близькі значення коефіцієнта кущіння $(2,68)$ до варіанту з $\mathrm{N}_{30} \mathrm{P}_{30} \mathrm{~K}_{30}$. Тільки органічний фон живлення дав дещо нижчий результат. Коефіцієнт кущіння в цих варіантах був на 0,33 більшим за контроль. 
Результати дослідів показали, що найкраще впливали на біометричні показники мінеральний та органо-мінеральний фони живлення.

У ячменю ярого сорту Аверс коефіцієнт кущіння та коефіцієнт продуктивного кущіння при використанні органічного добрива в різних варіантах обробок збільшилися порівняно з контролем без добрив. Так, найбільший, показник коефіцієнта загального кущіння було отримано при внесенні мінеральних добрив $(2,67)$, він перевищив контроль на 0,93 (табл. 8).

Таблиця 8

Біометричні показники ячменю ярого сорту Аверс на початку фази воскової стиглості (середнє за 2011-2015 рр.)

\begin{tabular}{|c|c|c|c|c|}
\hline \multirow{2}{*}{ Варіант } & \multicolumn{2}{|c|}{ Кількість стебел, шт./м² } & \multicolumn{2}{|c|}{ Коефіцієнт кущіння } \\
\hline & загальна & продуктивна & загальний & продуктивний \\
\hline $\begin{array}{l}\text { Контроль - } \\
\text { без добрив }\end{array}$ & 764 & 422 & 1,74 & 0,96 \\
\hline $\mathrm{N}_{30} \mathrm{P}_{30} \mathrm{~K}_{30}$ & 1171 & 614 & 2,67 & 1,40 \\
\hline Біогумус-1 & 921 & 512 & 2,14 & 1,19 \\
\hline Біогумус-2 & 918 & 465 & 2,17 & 1,10 \\
\hline $\begin{array}{l}\text { Біогумус-1+ } \\
\mathrm{N}_{15} \mathrm{P}_{15} \mathrm{~K}_{15}\end{array}$ & 1117 & 589 & 2,54 & 1,34 \\
\hline $\begin{array}{l}\text { Біогумус-2 + } \\
\mathrm{N}_{15} \mathrm{P}_{15} \mathrm{~K}_{15}\end{array}$ & 1106 & 562 & 2,56 & 1,30 \\
\hline $\begin{array}{l}\text { Біогумус-1+ } \\
\text { Стимпо }\end{array}$ & 993 & 551 & 2,29 & 1,27 \\
\hline $\begin{array}{l}\text { Біогумус-2+ } \\
\text { Стимпо }\end{array}$ & 978 & 561 & 2,25 & 1,29 \\
\hline $\begin{array}{l}\text { Біогумус-1+ } \\
\text { Регоплант }\end{array}$ & 989 & 539 & 2,33 & 1,27 \\
\hline $\begin{array}{l}\text { Біогумус-2+ } \\
\text { Регоплант }\end{array}$ & 980 & 542 & 2,26 & 1,25 \\
\hline $\begin{array}{l}\text { Біогумус-1+ } \\
\mathrm{N}_{15} \mathrm{P}_{15} \mathrm{~K}_{15}+ \\
\text { Стимпо }\end{array}$ & 1141 & 599 & 2,59 & 1,36 \\
\hline $\begin{array}{l}\text { Біогумус- } \\
\text { 1+N15 } \mathrm{P}_{15} \mathrm{~K}_{15}+ \\
\text { Регоплант }\end{array}$ & 1155 & 630 & 2,64 & 1,44 \\
\hline $\begin{array}{l}\text { Біогумус-2+ } \\
\mathrm{N}_{15} \mathrm{P}_{15} \mathrm{~K}_{15+} \\
\text { Стимпо }\end{array}$ & 1120 & 577 & 2,60 & 1,34 \\
\hline $\begin{array}{l}\text { Біогумус-2+ } \\
\mathrm{N}_{15} \mathrm{P}_{15} \mathrm{~K}_{15}+ \\
\text { Регоплант }\end{array}$ & 1129 & 595 & 2,60 & 1,37 \\
\hline
\end{tabular}


Коефіцієнт продуктивного кущіння виявився найбільшим $(1,44)$ на варіанті, де посіви оброблялись біостимулятором Регоплант на органо-мінеральному фоні - Біогумус-1 3 дозою мінерального добрива $\mathrm{N}_{15} \mathrm{P}_{15} \mathrm{~K}_{15}$. Застосування цього регулятору росту рослин зумовило підвищення коефіцієнтів загального і продуктивного кущіння порівняно з контролем та мінеральним фоном живлення.

Застосування органічних біодобрив і біостимуляторів суттєво вплинуло на показники структури врожаю. Так, за внесення добрив у грунт висота рослин була більшою за контроль на 2,3-5,2 см. У варіантах з обприскуванням посівів у фазі кущіння на фоні внесення органічних добрив у грунт рослини були вищими ніж у інших варіантах досліду, їх висота становила 59,9-62,8 см і перевищувала контроль на 3,1-6,0 см.

Найбільше значення показника довжина колосу (+1,2 см порівняно $з$ контролем) відмічали при використанні Регопланту при обприскуванні посівів на фоні внесення Біогумусу-1 з половинною дозою добрив, а також за внесення $\mathrm{N}_{30} \mathrm{P}_{30} \mathrm{~K}_{30}$ (табл. 9).

Кількість зерен у колосі перевищила контроль у всіх варіантах досліду. Найбільші значення цей показник мав на фонах $\mathrm{N}_{30} \mathrm{P}_{30} \mathrm{~K}_{30}$ та біогумусу i $\mathrm{N}_{15} \mathrm{P}_{15} \mathrm{~K}_{15} 3$ додатковим обприскуванням посівів біостимуляторами Регоплант і Стимпо. На цих варіантах прибавка порівняно з контролем становила 1,8-2,5 шт. зерен.

Маса 1000 зерен була більшою за контроль на всіх варіантах досліду. Це збільшення було від 0,7 г до 2,7 г порівняно 3 контролем. Максимальною (44,6 г) маса 1000 зерен була за сумісного використання Біогумус-1 $3 \quad \mathrm{~N}_{15} \mathrm{P}_{15} \mathrm{~K}_{15}$. Обприскування посівів біостимуляторами Регоплант і Стимпо на фоні внесення в грунт біогумусу також призвело до суттєвого збільшення цього показника на 1,0-2,0 г, відносно контролю. Таким чином, аналіз показників структури врожаю ячменю ярого показав, що застосування біогумусу дозволяє зменшити дозу використання мінеральних добрив.

Найбільша прибавка врожаю зерна 0,73 т/га (31,7 \%) порівняно 3 контролем була отримана на варіанті, де застосовували тільки мінеральну систему живлення $\mathrm{N}_{30} \mathrm{P}_{30} \mathrm{~K}_{30}$. За рахунок внесення половинної дози мінеральних добрив разом з Біогумусом-1 i Біогумусом-2 одержали додатковий приріст врожаю 0,54 т/га $(23,65 \%)$ і 0,47 т/га (20,3 \%) відповідно. 
Таблиця 9

Показники структури врожаю ячменю ярого сорту Аверс при застосуванні добрив і біостимуляторів (середнє за 2011-2015 рр.)

\begin{tabular}{|c|c|c|c|c|c|}
\hline Варіант досліду & $\begin{array}{c}\text { Висота } \\
\text { рослин, } \\
\text { см }\end{array}$ & \begin{tabular}{|c} 
Довжина \\
колосу, \\
см
\end{tabular} & $\begin{array}{c}\text { Кількість } \\
\text { зерен } \\
\text { у колосі, } \\
\text { шт. } \\
\end{array}$ & \begin{tabular}{|c|} 
Maca \\
1000 \\
зерен, \\
$\Gamma$ \\
\end{tabular} & $\begin{array}{c}\text { Натура } \\
\text { зерна, } \\
\text { г/л }\end{array}$ \\
\hline Контроль - без добрив & 56,8 & 6,3 & 12,5 & 41,9 & 556,2 \\
\hline $\mathrm{N}_{30} \mathrm{P}_{30} \mathrm{~K}_{30}$ & 2,1 & 7,5 & 14,7 & 44,5 & 583,7 \\
\hline Біогумус-1 & 58,6 & 6,9 & 13,3 & 42,9 & 569,3 \\
\hline Біогумус-2 & 59,1 & 6,7 & 13,0 & 42,6 & 568,0 \\
\hline Біогумус- $1+\mathrm{N}_{15} \mathrm{P}_{15} \mathrm{~K}_{15}$ & 60,1 & 7,2 & 14,2 & 43,8 & 580,3 \\
\hline Біогумус-2 + $\mathrm{N}_{15} \mathrm{P}_{15} \mathrm{~K}_{15}$ & 60,5 & 6,7 & 14,0 & 43,2 & 579,4 \\
\hline Біогумус-1 + Стимпо & 60,2 & 7,0 & 13,9 & 43,0 & 569,5 \\
\hline Біогумус-2 + C & 59,9 & 6,8 & 13,9 & 42,9 & 567,9 \\
\hline Біогумус-1 + & 60,8 & 7,0 & 13,6 & 43,9 & 573,0 \\
\hline Біогумус- $2+$ & & 7,0 & 13,7 & 43,9 & 580,0 \\
\hline $\begin{array}{l}\text { Біогумус-1 + } \mathrm{N}_{15} \mathrm{P}_{15} \mathrm{~K}_{15}+ \\
\text { Стимпо }\end{array}$ & 61,9 & 7,4 & 14,7 & 44,2 & 579,5 \\
\hline $\begin{array}{l}\text { Біогумус-1+ } \mathrm{N}_{15} \mathrm{P}_{15} \mathrm{~K}_{15}+ \\
\text { Регоплант }\end{array}$ & 62,8 & 7,5 & 15,0 & 44,6 & 581,7 \\
\hline $\begin{array}{l}\text { Біогумус-2+ } \mathrm{N}_{15} \mathrm{P}_{15} \mathrm{~K}_{15}+ \\
\text { Стимпо }\end{array}$ & 60,9 & 7,1 & 14,3 & 43,7 & 571,0 \\
\hline $\begin{array}{l}\text { Біогумус-2+ } \mathrm{N}_{15} \mathrm{P}_{15} \mathrm{~K}_{15}+ \\
\text { Регоплант }\end{array}$ & 62,0 & 7,1 & 14,9 & 44,0 & 569,5 \\
\hline $\mathrm{HIP}_{0,5}$ & $1,7-1,9$ & $0,10-0,12$ & $0,1-0,4$ & $0,2-0,6$ & $5,3-6,7$ \\
\hline
\end{tabular}

Обприскування рослин ячменю ярого біостимуляторами на фоні органо-мінеральної системи живлення забезпечило одержання додаткового врожаю порівняно з контролем.

Найвищою прибавка була за використання біостимулятора Регоплант і становила 0,66 т/га або 28,8 \% відносно контролю.

Таким чином, застосування біогумусу різного походження дає змогу скоротити витрати мінеральних добрив, тим самим зменшити антропогенне навантаження на агроландшафти при збереженні рівня врожайності. 
Формування нової парадигми розвитку агропромислового сектору в XXI столітті

\section{3. Ефективність застосування нових поживних комплексів} та їх вплив на ріст і розвиток рослин ячменю ярого

Одним із напрямків досліджень було створення поживних комплексів на основі отриманих багаторічних експериментальних даних, які б могли задовільнити вимоги рослин у поживних речовинах в основні етапи онтогенезу.

У фазі кущіння проводився відбір рослин ячменю ярого для проведення біометричного аналізу розвитку культур на даному етапі (табл. 10).

Таблиця 10

Стан рослин ячменю ярого сорту Східний у фазі кущіння залежно від поживного комплексу та фону живлення (середнє за 2014-2018 рр.)

\begin{tabular}{|c|c|c|c|c|c|}
\hline Варіант & $\begin{array}{c}\text { Висота } \\
\text { рослин, } \\
\text { см }\end{array}$ & $\begin{array}{c}\text { Кількість } \\
\text { стебел, } \\
\text { шт./м² }\end{array}$ & $\begin{array}{c}\text { Кількість } \\
\text { вузл. } \\
\text { коренів, } \\
\text { шт./м² } \\
\end{array}$ & $\begin{array}{c}\text { Коеф. } \\
\text { кущіння }\end{array}$ & $\begin{array}{c}\text { Кількість } \\
\text { вузлових } \\
\text { коренів, } \\
\text { шт. } \\
\end{array}$ \\
\hline 1 & 2 & 3 & 4 & 5 & 6 \\
\hline \multicolumn{6}{|c|}{ Фон $1-\mathrm{N}_{30} \mathrm{P}_{30} \mathrm{~K}_{30}$} \\
\hline Контроль & 37,6 & 1010 & 419 & 2,24 & 0,93 \\
\hline $\begin{array}{l}\text { Хімічний } \\
\text { захист посівів }\end{array}$ & 40,3 & 1123 & 475 & 2,50 & 1,06 \\
\hline $\begin{array}{l}\text { Біологічний } \\
\text { захист посівів }\end{array}$ & 40,5 & 1121 & 571 & 2,49 & 1,27 \\
\hline Комплекс $1^{*}$ & 43,9 & 1199 & 559 & 2,66 & 1,24 \\
\hline Комплекс $2^{* *}$ & 44,3 & 1255 & 567 & 2,79 & 1,26 \\
\hline Комплекс $3^{* * *}$ & 44,5 & 1301 & 569 & 2,89 & 1,26 \\
\hline \multicolumn{6}{|c|}{ Фон 2 - N ${ }_{15} \mathrm{P}_{15} \mathrm{~K}_{15}+$ біогумус (250 кг/га) } \\
\hline Контроль & 39,3 & 1006 & 398 & 2,24 & 0,88 \\
\hline $\begin{array}{l}\text { Хімічний } \\
\text { захист посівів }\end{array}$ & 43,3 & 1117 & 442 & 2,48 & 0,98 \\
\hline $\begin{array}{l}\text { Біологічний } \\
\text { захист посівів }\end{array}$ & 41,1 & 1215 & 433 & 2,70 & 0,96 \\
\hline Комплекс $1^{*}$ & 47,4 & 1267 & 477 & 2,82 & 1,06 \\
\hline Комплекс $2^{* *}$ & 45,4 & 1356 & 526 & 3,01 & 1,17 \\
\hline Комплекс $3^{* * *}$ & 46,4 & 1341 & 548 & 2,98 & 1,23 \\
\hline \multicolumn{6}{|c|}{ Фон 3 - біогумус (250 кг/га) } \\
\hline Контроль & 37,6 & 971 & 331 & 2,16 & 0,74 \\
\hline $\begin{array}{l}\text { Хімічний } \\
\text { захист посівів }\end{array}$ & 39,1 & 987 & 393 & 2,19 & 0,87 \\
\hline
\end{tabular}


Закінчення таблиці 10

\begin{tabular}{|l|c|c|c|c|c|}
\hline \multicolumn{1}{|c|}{1} & 2 & 3 & 4 & 5 & 6 \\
\hline $\begin{array}{l}\text { Біологічний } \\
\text { захист посівів }\end{array}$ & 38,7 & 979 & 435 & 2,18 & 0,97 \\
\hline Комплекс 1 & 39,9 & 1118 & 453 & 2,48 & 1,01 \\
\hline Комплекс 2** & 38,4 & 1121 & 445 & 2,49 & 0,99 \\
\hline Комплекс 3** & 40,0 & 1115 & 478 & 2,48 & 1,06 \\
\hline
\end{tabular}

Примітка: *0бробка насіння препаратом Rost-Forte $(0,5$ л/га) у суміші 3 комплексом амінокислот, обприскування рослин у фазах кущіння та колосіння сумішшю препаратів Rost-концентрат 15.7.7. (1 л/га) + комплекс амінокислот + Хелатин (2 л/га) + мікробіологічний комплекс (400 г/га).

** Обробка насіння препаратом Айдар (1 л/т), обприскування рослин у фазах кущіння та колосіння сумішшю препарат Айдар (2 л/га) та мікробіологічного комплексу (400 г/га).

${ }^{* * *}$ Обробка насіння препаратом Сизам (250 г/т) у суміші з мікробіологічним комплексом, обприскування рослин у фазі кущіння сумішшю препарату Сизам (250 г/га) та мікробіологічного комплексу (400 г/га).

Встановлено, що на мінеральному фоні живлення найбільше підвищення біометричних показників порівняно з контролем відмічається при застосуванні нових поживних комплексів. Так, найвищі рослини були отримані при використанні поживного комплексу 3 (+ 6,9 см порівняно з контролем). Також на цьому варіанті була найбільшою кількість продуктивних стебел, i, як наслідок, коефіцієнт продуктивного кущіння, який перевищив контрольний варіант на 0,65.

Застосування поживних комплексів при вирощуванні ячменю ярого на мінеральному фоні живлення сприяло підвищенню кількості вторинних коренів порівняно з контролем від 0,31 шт. до 0,33 шт. та порівняно з хімічним захистом посівів - від 0,18 шт. до 0,20 шт.

На органо-мінеральному фоні живлення найвищими рослини були при застосуванні поживного комплексу 1 (прибавка до контролю склала 8,1 см). Кількість стебел найбільшою була за поживного комплексу 2 (+350 шт./м² порівняно 3 контролем). Використання поживних комплексів на органо-мінеральному фоні також стимулювало більш інтенсивний розвиток вторинної кореневої системи збільшивши кількість вузлових коренів порівняно з контролем від 79 шт./м² (поживний комплекс 1) до 140 шт./м² (поживний комплекс 3).

На органічному фоні живлення найбільше підвищення коефіцієнта кущіння було отримано при застосуванні поживного 
комплексу 2. Найбільша кількість вторинних коренів (+147 шт./м² порівняно з контролем) та найвищі рослини (+2,4 см до контролю) були у варіанті використання поживного комплексу 3.

При порівнянні трьох фонів живлення між собою було встановлено, що найкращий вплив на біометричні показники мали мінеральний та органо-мінеральний фони.

Найвище зростання коефіцієнта загального кущіння порівняно 3 контролем на мінеральному фоні живлення було відмічено при застосуванні мікробіологічних препаратів - +0,41 порівняно 3 контролем (табл. 11).

Таблиця 11

Густота стеблостою рослин ячменю ярого сорту Східний у фазі повної стиглості, середнє за 2014-2018 рр.

\begin{tabular}{|c|c|c|c|c|c|}
\hline \multirow{2}{*}{\multicolumn{2}{|c|}{ Варіант }} & \multicolumn{2}{|c|}{ Кількість стебел, шт./м² } & \multicolumn{2}{|c|}{ Коеф. кущіння } \\
\hline & & загальна & продуктивна & загальний & продуктивний \\
\hline \multicolumn{6}{|c|}{ Фон $1-\mathrm{N}_{30} \mathrm{P}_{30} \mathrm{~K}_{30}$} \\
\hline Контроль & & 1007,5 & 563,0 & 2,24 & 1,25 \\
\hline $\begin{array}{l}\text { Хімічний } \\
\text { посівів }\end{array}$ & захист & 1185,0 & 651,5 & 2,63 & 1,45 \\
\hline $\begin{array}{l}\text { Біологічний } \\
\text { посівів }\end{array}$ & захист & 1193,5 & 661,0 & 2,65 & 1,47 \\
\hline Комплекс $1^{*}$ & & 1146,0 & 584,0 & 2,55 & 1,30 \\
\hline Комплекс $2^{* *}$ & & 1171,0 & 628,0 & 2,60 & 1,40 \\
\hline Комплекс $3^{* * *}$ & & 1169,0 & 654,0 & 2,60 & 1,45 \\
\hline \multicolumn{6}{|c|}{ Фон 2 - N $15 \mathrm{P}_{15} \mathrm{~K}_{15}+$ біогумус (250 кг/га) } \\
\hline Контроль & & 998,5 & 430,5 & 2,22 & 0,96 \\
\hline $\begin{array}{l}\text { Хімічний } \\
\text { посівів }\end{array}$ & захист & 1177,5 & 603,0 & 2,62 & 1,34 \\
\hline $\begin{array}{l}\text { Біологічний } \\
\text { посівів }\end{array}$ & захист & 1150,0 & 586,0 & 2,56 & 1,30 \\
\hline Комплекс $1^{*}$ & & 1190,0 & 526,0 & 2,64 & 1,17 \\
\hline Комплекс $2^{* *}$ & & 1164,0 & 661,5 & 2,59 & 1,47 \\
\hline Комплекс $3^{* * *}$ & & 1173,0 & 647,7 & 2,61 & 1,44 \\
\hline \multicolumn{6}{|c|}{ Фон 3 - біогумус (250 кг/га) } \\
\hline Контроль & & 804,0 & \begin{tabular}{|l|}
432,5 \\
\end{tabular} & 1,79 & 0,96 \\
\hline $\begin{array}{l}\text { Хімічний } \\
\text { посівів }\end{array}$ & захист & 978,5 & 495,0 & 2,17 & 1,10 \\
\hline $\begin{array}{l}\text { Біологічний } \\
\text { посівів }\end{array}$ & захист & 921,0 & 533,5 & 2,05 & 1,19 \\
\hline Комплекс $1^{*}$ & & 967,0 & 588,5 & 2,15 & 1,31 \\
\hline Комплекс $2^{* *}$ & & 992,5 & 571,0 & 2,21 & 1,27 \\
\hline Комплекс $3^{* * *}$ & & 997,8 & 579,0 & 2,22 & 1,29 \\
\hline
\end{tabular}


Що стосовно коефіцієнта продуктивного кущіння, то всі варіанти, які вивчалися, сприяли збільшенню цього показника порівняно 3 контролем. Найбільше зростання було відмічене при застосуванні мікробіологічних препаратів для стимуляції ростових процесів та захисту рослин від шкідників та хвороб.

Найменше зростання коефіцієнтів загального та продуктивного кущіння порівняно з контролем на мінеральному фоні живлення відмічали при використанні поживного комплексу 1 (+0,31 та +0,05, відповідно).

На органо-мінеральному фоні застосування поживного комплексу 1 сприяло збільшенню загальної кількості стебел порівняно $з$ контролем на 174,5 шт./м². Це найкращий варіант на даному фоні. А найбільшу кількість продуктивних стебел було сформовано рослинами при використанні поживного комплексу 2 (+231 шт./м² порівняно з контролем).

На органічному фоні при використанні поживних комплексів було відмічено збільшення коефіцієнтів, як загального, так i продуктивного кущіння, порівняно 3 контролем. Найвищий коефіцієнт загального кущіння був отриманий на варіанті застосування поживного комплексу $3(2,22)$, а коефіцієнт продуктивного кущіння - поживного комплексу 1 (1,31).

Порівнюючи три фони живлення, можна зробити висновок, що найбільший вплив поживних комплексів, що вивчались, був при використанні органічного фону. Тобто, на цьому фоні були отримані найвищі прирости коефіцієнтів загального та продуктивного кущіння порівняно з контролем.

У процесі дослідження впливу поживних комплексів на показники структури врожайності ячменю ярого сорту Східний було встановлено, що на мінеральному фоні живлення найкращі результати були отримані при застосуванні поживного комплексу 3 - довжина колосу збільшилась порівняно з контролем на 1,7 см, кількість зерен у колосі - на 2,1 шт., маса 1000 зерен - на 2,8 г (табл. 12).

На органо-мінеральному фоні спостерігалася подібна ситуація, а органічний фон живлення сприяв отриманню найкращих показників структури врожайності при застосуванні поживного комплексу 2. Так, довжина колоса збільшилась порівняно 3 контролем на 2,4 см, кількість зерен у колосі - на 2,4 шт., маса 1000 зерен - на 2,9 г. 
Таблиця 12

Показники структури урожайності зерна ячменю ярого сорту Східний (середнє за 2014-2018 рр.)

\begin{tabular}{|c|c|c|c|c|c|}
\hline Варіант & $\begin{array}{c}\text { Висота } \\
\text { рослин, } \\
\text { см }\end{array}$ & $\begin{array}{c}\text { Довжина } \\
\text { колосу, } \\
\text { см }\end{array}$ & $\begin{array}{c}\text { Кількість } \\
\text { зерен } \\
\text { у колосі, } \\
\text { шт. }\end{array}$ & $\begin{array}{c}\text { Маса } \\
1000 \\
\text { зерен, Г }\end{array}$ & $\begin{array}{c}\text { Натура } \\
\text { зерна, } \\
\text { г/л }\end{array}$ \\
\hline \multicolumn{6}{|c|}{ ФоH $1-\mathrm{N}_{30} \mathrm{P}_{30} \mathrm{~K}_{30}$} \\
\hline Контроль & 59,6 & 8,4 & 13,0 & 43,1 & 586,0 \\
\hline $\begin{array}{l}\text { Хімічний захист } \\
\text { посівів }\end{array}$ & 62,1 & 8,9 & 13,6 & 44,9 & 586,7 \\
\hline $\begin{array}{l}\text { Біологічний } \\
\text { захист посівів }\end{array}$ & 63,5 & 9,0 & 13,9 & 45,7 & 587,4 \\
\hline Комплекс $1^{*}$ & 63,6 & 9,8 & 14,7 & 45,5 & 587,3 \\
\hline Комплекс $2^{* *}$ & 63,4 & 9,9 & 14,9 & 45,4 & 589,5 \\
\hline Комплекс $3^{* * *}$ & 64,3 & 10,1 & 15,1 & 45,9 & 588,4 \\
\hline $\mathrm{HIP}_{0,5}$ & $0,2-0,5$ & $0,3-0,6$ & $0,7-0,9$ & $0,5-0,9$ & $0,7-1,5$ \\
\hline \multicolumn{6}{|c|}{ Фон 2 - N $15 \mathrm{P}_{15} \mathrm{~K}_{15}+$ біогумус (250 кг /га) } \\
\hline Контроль & 60,9 & 8,0 & 12,5 & 42,1 & 579,5 \\
\hline $\begin{array}{l}\text { Хімічний захист } \\
\text { посівів }\end{array}$ & 63,1 & 9,3 & 12,9 & 43,4 & 581,7 \\
\hline \begin{tabular}{|l} 
Біологічний \\
захист посівів
\end{tabular} & 62,5 & 9,7 & 13,5 & 44,4 & 579,5 \\
\hline Комплекс 1* & 63,2 & 10,1 & 14,7 & 44,9 & 581,3 \\
\hline Комплекс $2^{* *}$ & 62,9 & 10,7 & 13,9 & 44,7 & 565,1 \\
\hline Комплекс $3^{* * *}$ & 63,6 & 11,0 & 14,9 & 45,0 & 573,0 \\
\hline $\mathrm{HIP}_{0,5}$ & $0,6-0,9$ & $0,1-0,4$ & $0,6-0,9$ & $0,3-0,5$ & $0,4-1,3$ \\
\hline \multicolumn{6}{|c|}{ Фон 3 - біогумус (250 кг/га) } \\
\hline Контроль & 58,0 & 7,5 & 12,1 & 41,9 & 556,2 \\
\hline $\begin{array}{l}\text { Хімічний захист } \\
\text { посівів }\end{array}$ & 61,8 & 8,7 & 13,9 & 42,2 & 588,7 \\
\hline \begin{tabular}{|l|} 
Біологічний \\
захист посівів
\end{tabular} & 61,5 & 8,9 & 13,7 & 43,5 & 567,9 \\
\hline Комплекс $1^{*}$ & 62,7 & 9,5 & 14,0 & 44,5 & 571,0 \\
\hline Комплекс $2^{* *}$ & 62,2 & 9,9 & 14,5 & 44,8 & 562,4 \\
\hline Комплекс $3^{* * *}$ & 62,8 & 9,7 & 13,9 & 44,2 & 569,5 \\
\hline $\begin{array}{l}\text { HIP05 для: } \\
\text { варіанту досліду }\end{array}$ & $0,7-0,9$ & $0,1-0,2$ & $0,1-0,2$ & $1,3-1,4$ & $1,7-1,9$ \\
\hline фону живлення & $0,5-0,6$ & $0,1-0,2$ & $0,1-0,2$ & $1,0-1,1$ & $2,6-3,1$ \\
\hline взаємодії & $1,0-1,2$ & $0,2-0,3$ & $0,2-0,3$ & $1,6-1,8$ & $3,7-4,2$ \\
\hline
\end{tabular}


При порівнянні двох варіантів захисту рослин від шкідників та хвороб, було встановлено, що незалежно від фону живлення найкращих показників структури врожайності було досягнуто при використанні біологічного захисту посівів (застосування мікробіологічних препаратів для інокуляції насіння та обприскування посівів). Так, на мінеральному фоні живлення при біологічному захисті посівів довжина колоса була більшою за варіант хімічного захисту на 0,1 см, зерен у колосі було більше на 0,3 шт., а маса 1000 зерен збільшилась на 0,8 г.

На органо-мінеральному фоні живлення біологічний захист посівів забезпечив видовження колосу порівняно 3 хімічним захистом на 0,4 см, кількість зерен у колосі збільшилась на 0,6 шт., а маса 1000 зерен - на 1 г.

Порівняння фонів живлення демонструє, що при використанні мінерального фону були отримані найвищі показники структури врожайності, незалежно від варіантів, що вивчалися. А органічний та органо-мінеральний фони сприяли отриманню найвищих показників структури врожайності порівняно з контролем.

Таким чином, одержаний на основі польових досліджень експериментальний матеріал, дає змогу стверджувати, що застосування поживних комплексів забезпечує необхідний стартовий ефект на початковому етапі розвитку рослин, сприяє підвищенню продуктивності та урожайності ячменю ярого.

При визначенні ефективності вказаних комплексів на рівень врожайності зерна ячменю ярого сорту Східний встановлено, що використання поживного комплексу 3 на мінеральному фоні живлення забезпечило прибавку врожайності зерна 1,37 т/га, або $51,9 \%$, порівняно з контролем (табл. 13 ).

Органо-мінеральний фон живлення у поєднанні з поживним комплексом 3 сприяв отриманню приросту врожайності 2,08 т/га до контролю. На органічному фоні живлення найвищу прибавку врожайності (1,60 т/га) забезпечило використання поживного комплексу 1.

Взагалі можна зробити висновок, що застосування нових поживних комплексів у поєднанні 3 органічним та органомінеральним фоном живлення сприяє доброму росту та розвитку рослин протягом вегетації, що в свою чергу, забезпечує формування кращих показників структури врожайності, а як наслідок, i врожайності ячменю ярого сорту Східний в умовах східної частини Північного Степу. 
Таблиця 13

Урожайність зерна ячменю ярого (середнє за 2014-2018 рр.)

\begin{tabular}{|c|c|c|c|}
\hline \multirow{2}{*}{ Варіант } & \multirow{2}{*}{$\begin{array}{c}\text { Урожайність, } \\
\text { т/га }\end{array}$} & \multicolumn{2}{|c|}{ Прибавка урожаю } \\
\hline & & т/га & $\%$ \\
\hline \multicolumn{4}{|c|}{ ФоH $1-\mathrm{N}_{30} \mathrm{P}_{30} \mathrm{~K}_{30}$} \\
\hline Контроль & 2,63 & - & - \\
\hline Хімічний захист посівів & 3,01 & 0,43 & 16,16 \\
\hline Біологічний захист посівів & 3,81 & 1,18 & 44,68 \\
\hline Комплекс 1 & 3,46 & 0,83 & 31,56 \\
\hline Комплекс 2 & 3,71 & 1,08 & 41,06 \\
\hline Комплекс 3 & 3,99 & 1,36 & 51,90 \\
\hline \multicolumn{4}{|c|}{ Фон $2-\mathrm{N}_{15} \mathrm{P}_{15} \mathrm{~K}_{15}+$ біогумус (250 кг/га) } \\
\hline Контроль & 1,78 & - & - \\
\hline Хімічний захист посівів & 2,88 & 1,10 & 61,80 \\
\hline Біологічний захист посівів & 3,04 & 1,26 & 70,79 \\
\hline Комплекс 1 & 3,01 & 1,23 & 69,10 \\
\hline Комплекс 2 & 3,61 & 1,83 & 102,81 \\
\hline Комплекс 3 & 3,86 & 2,08 & 116,85 \\
\hline \multicolumn{4}{|c|}{ Фон 3 - біогумус (250 кг/га) } \\
\hline Контроль & 1,65 & - & - \\
\hline Хімічний захист посівів & 2,43 & 0,78 & 47,27 \\
\hline Біологічний захист посівів & 2,68 & 1,03 & 62,42 \\
\hline Комплекс 1 & 3,25 & 1,60 & 96,97 \\
\hline Комплекс 2 & 3,21 & 1,56 & 94,55 \\
\hline Комплекс 3 & 3,05 & 1,40 & 84,85 \\
\hline
\end{tabular}

Аналіз економічної ефективності використання поживних комплексів на мінеральному фоні живлення показав значну роль запропонованих варіантів для підвищення рівня рентабельності виробництва ячменю ярого (табл. 14). Так, на цьому фоні живлення, 3 використанням поживного комплексу 3 , рівень рентабельності становив 107,4\%, це найвищий показник серед інших поживних комплексів та другий після біологічного захисту посівів $(116,1 \%)$. Собівартість 1 т зерна цього варіанту була 2130 грн. Проте, на мінеральному фоні живлення ми отримали найвищі витрати сукупної енергії, які склали від 9895 МДж до 12603 МДж на 1 га. Коефіцієнт енергетичної ефективності підвищувався при застосуванні поживних комплексів від 0,15 до 1,31, порівняно 3 контролем. 
Таблиця 14

\section{Економічна та біоенергетична ефективність вирощування ячменю ярого залежно від фону живлення та поживного комплексу (середнє за 2014-2018 рр.)}

\begin{tabular}{|c|c|c|c|c|c|c|}
\hline \multirow[b]{2}{*}{ Показники } & \multicolumn{6}{|c|}{ Варіанти досліду } \\
\hline & $\begin{array}{l}\text { ही } \\
0 \\
0 \\
0 \\
0 \\
0\end{array}$ & 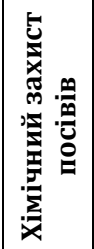 & 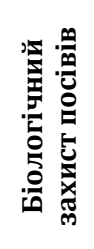 & 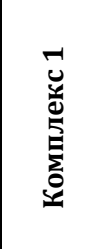 & 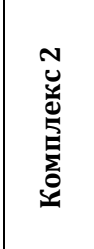 & 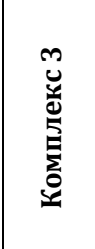 \\
\hline \multicolumn{7}{|c|}{ ФоH - N30P30K30 } \\
\hline Урожайність, т/га & 2,63 & 3,01 & 3,81 & 3,46 & 3,71 & 3,99 \\
\hline Виробничі витрати, грн/га & 7003 & 8260 & 7786 & 8859 & 8730 & 8497 \\
\hline Собівартість 1 т зерна, грн & 2663 & 2744 & 2044 & 2560 & 2353 & 2130 \\
\hline Чистий дохід, грн: на 1 га & 4613 & 5034 & 9041 & 6423 & 7656 & 9126 \\
\hline на $1 \mathrm{~T}$ & 1754 & 1672 & 2373 & 1856 & 2064 & 2287 \\
\hline Рівень рентабельності, \% & 65,9 & 60,9 & 116,1 & 72,5 & 87,7 & 107,4 \\
\hline Затрати сукупної енергії, МДж/га & 9895 & 10503 & 11009 & 12603 & 12403 & 11559 \\
\hline Енергоємкість 1 т зерна, МДж & 3762 & 3489 & 2889 & 3643 & 3343 & 2897 \\
\hline $\begin{array}{l}\text { Коефіцієнт енергетичної } \\
\text { ефективності }\end{array}$ & 4,37 & 4,71 & 5,69 & 4,52 & 4,92 & 5,68 \\
\hline \multicolumn{7}{|c|}{ Фон - N15 $\mathrm{P}_{15} \mathrm{~K}_{15}+$ біогумус $(250$ кг/га) } \\
\hline Урожайність, т/га & 1,78 & 2,88 & 3,04 & 3,01 & 3,61 & 3,86 \\
\hline Виробничі витрати, грн/га & 6731 & 8418 & 7563 & 8826 & 8906 & 8655 \\
\hline Собівартість 1 т зерна, грн & 3782 & 2923 & 2488 & 2932 & 2467 & 2242 \\
\hline Чистий дохід, грн: на 1 га & 1131 & 4302 & 5864 & 4468 & 7038 & 8393 \\
\hline на $1 \mathrm{~T}$ & 635 & 1494 & 1929 & 1484 & 1950 & 2174 \\
\hline Рівень рентабельност & 16,8 & 51,1 & 77,5 & 50,6 & 79,0 & 97,0 \\
\hline Затрати сукупної енергії, МДж/га & 9111 & 10373 & 10298 & 12183 & 12300 & 11429 \\
\hline Енергоємкість 1 т зерна, МДж & 5119 & 3602 & 3387 & 4047 & 3407 & 2961 \\
\hline $\begin{array}{l}\text { Коефіцієнт енергетичної } \\
\text { ефективності }\end{array}$ & 3,21 & 4,57 & 4,86 & 4,06 & 4,83 & 5,56 \\
\hline \multicolumn{7}{|c|}{ Фон - біогумус (250 кг/га) } \\
\hline Урожайність, т/га & 1,65 & 2,43 & 2,68 & 3,25 & 3,21 & 3,05 \\
\hline Виробничі витрати, грн/га & 5888 & 7384 & 6582 & 8204 & 7902 & 7406 \\
\hline Собівартість 1 т зерна, грн & 3568 & 3039 & 2456 & 2524 & 2462 & 2428 \\
\hline Чистий дохід, грн: на 1 га & 1399 & 3348 & 5254 & 6150 & 6276 & 6065 \\
\hline на $1 \mathrm{~T}$ & 848 & 1378 & 1961 & 1892 & 1955 & 1988 \\
\hline Рівень рентабельності, \% & 23,8 & 45,3 & 79,8 & 75,0 & 79,4 & 81,9 \\
\hline Затрати сукупної енергії, МДж/га & 8278 & 9249 & 9255 & 11686 & 11222 & 9978 \\
\hline Енергоємкість 1 т зерна, МДж & 5017 & 3806 & 3454 & 3596 & 3496 & 3272 \\
\hline $\begin{array}{l}\text { Коефіцієнт енергетичної } \\
\text { ефективності }\end{array}$ & 3,28 & 4,32 & 4,76 & 4,58 & 4,71 & 5,03 \\
\hline
\end{tabular}


На органо-мінеральному фоні поживний комплекс 3 також забезпечив найвищі показники економічної ефективності. Так, собівартість 1 т зерна склала 2242 грн, чистий прибуток 8393,0 грн/га, рівень рентабельності - 97,0 \%, що на 80,2 \% перевищує контрольний варіант. Енергоємкість 1 т зерна при використанні поживних комплексів на цьому фоні живлення знижувалась порівняно з контролем від 1072 МДж до 2158 МДж. Коефіцієнт енергетичної ефективності найвищий був при застосуванні поживного комплексу $3(5,56)$.

На органічному фоні найкраще себе проявив поживний комплекс 3. Рівень рентабельності при застосуванні цього комплексу склав 81,9\%, собівартість 1 т зерна знизилась порівняно з контролем на 1140 грн.

На цьому ж варіанті, також, було отримано найвищий коефіцієнт енергетичної ефективності, який перевищив контроль по фону на 1,75 .

На органічному фоні живлення порівняно з іншими були також отримані найнижчі показники затрат сукупної енергії серед інших фонів.

Аналіз результатів демонструє цілковиту перевагу поживних комплексів над контролем та варіантом, де застосовувалися пестициди незалежно від фону живлення. Тому, можна зробити висновок, що нові поживні комплекси це універсальний засіб, який гарантовано забезпечить високий рівень доцільності вирощування ячменю ярого, особливо, в гостропосушливих регіонах східної частини Північного Степу.

\section{Висновки}

Впровадження нових поживних комплексів у технології вирощування пшениці озимої сприяло доброму розвитку рослин протягом всієї вегетації та дозволило сформувати врожайність, яка значно перевищила контрольний варіант. Найкращі показники серед представлених варіантів, незалежно від фону живлення, забезпечив поживний комплекс 3 (обробка насіння препаратом Сизам (250 г/т) у суміші з мікробіологічним комплексом, обприскування рослин у фазі кущіння сумішшю препарат Сизам (250 г/га) та мікробіологічний комплекс (400 г/га)). Так, на мінеральному $\left(\mathrm{N}_{30} \mathrm{P}_{30} \mathrm{~K}_{30}\right)$, органомінеральному $\left(\mathrm{N}_{15} \mathrm{P}_{15} \mathrm{~K}_{15}+\right.$ біогумус (250 кг/га)) та органічному (біогумус - 250 кг/га) фонах живлення, в середньому за роки проведення досліджень, використання комплексу 3 забезпечило 
приріст врожайності зерна порівняно з контролем склав 1,22 т/га (48,0 \%); 0,78 т/га (30,5\%) та 0,43 т/га (16,9\%) відповідно.

Розрахунок економічної та біоенергетичної ефективності використання нових поживних комплексів на різних фонах живлення при вирощування пшениці озимої свідчить про значну перевагу запропонованих елементів над контрольним варіантом. Найвищі коефіцієнти енергетичної ефективності були отримані при застосуванні також поживного комплексу 3: на мінеральному фоні живлення - 6,80; на органо-мінеральному фоні живлення 6,63; на органічному - 6,52.

Використання елементів біологізації в технології вирощування ячменю ярого суттєво впливає на ріст, розвиток рослин та формування врожайності зерна культури. Так, комплексне застосування Біогумусу-1 (250 кг/га) та біостимулятора Регоплант забезпечило врожайність зерна 2,95 т/га, приріст до контролю становив 0,66 т/га або 28,8\%.

Комплексне застосування біогумусу 3 біостимуляторами природного походження Регоплан та Стимпо дозволяє до $50 \%$ скоротити обсяги внесення традиційних мінеральних добрив, що зменшує ризик забруднення навколишнього середовища при збереженні рівня зернової продуктивності.

Використання нових поживних комплексів при вирощуванні ячменю ярого сприяло доброму розвитку рослин протягом всієї вегетації та дозволило сформувати на всіх фонах живлення врожайність, яка значно перевищила контроль: на фоні внесення $\mathrm{N}_{30} \mathrm{P}_{30} \mathrm{~K}_{30}$ прибавка урожаю порівняно з контролем склала 1,36 т/га, на органо-мінеральному фоні ( $\mathrm{N}_{15} \mathrm{P}_{15} \mathrm{~K}_{15}+$ біогумус, 250 кг/га) - 2,08 т/га, а на органічному фоні живлення (біогумус, 250 кг/га) - 1,60 т/га.

Розрахунок економічної ефективності використання поживних комплексів продемонстрував значну перевагу запропонованих варіантів у підвищенні рівня рентабельності виробництва зерна ячменю ярого. Найкращі економічні показники та коефіцієнт енергетичної ефективності на всіх фонах живлення були за використання поживного комплексу 3 (обробка насіння препаратом Сизам (250 г/т) у суміші з мікробіологічним комплексом, обприскування рослин у фазі кущіння сумішшю препарату Сизам (250 г/га) та мікробіологічного комплексу (400 г/га)). 


\section{Список використаних джерел:}

1. Гордецька С. П. Особливості формування високопродуктивних агрофітоценозів зернових колосових культур. Наукові основи ведення зернового господарства. Київ : Урожай, 1994. С. 54-70.

2. Лопачев Н. А., Наумкин В. Н., Петров В. А. Теоретические основы биологизации земледелия. Агрохимический вестник. 1998. № 5-6. С. 32-33.

3. Игонин А. М. Черви - гумус - урожай. Достижения науки и техники АПК. 2004. № 4. С. 2-3.

4. Прищепа И. А. Применение смесей пестицидов и регуляторов роста на посевах зерновых колосовых культур. Агрохимия. 1998. № 8. C. 74-89.

5. Михайловская Н. А., Волкова Н. Д. Диазотрофная бактеризация как перспективный биотехнологический приём при возделывании ячменя. Проблемы питания растений и использования удобрений в современных условиях : материалы межд. науч.-прак. конф. Жодино. 2000. С. 351-352.

6. Патика В. П., Гармашов В. В., Калініченко А. В. Морфофізіологічні дослідження впливу біопрепаратів азотфіксувальних бактерій на формування елементів продуктивності озимої пшениці. Физиология и биохимия культурных растений. 2004. Вып. 36. № 3. C. 239-248.

7. Волкогон В. В. Приёмы регулирования активности ассоциативной азотфиксации. Бюл. ІСГМ. УААН. 1997. № 1. С. 17-19.

8. Патика В. П., Татаріко Ю. О., Мельничук Т. М. Комплексне застосування біопрепаратів на основі азотфіксуючих, фосфоромобілізуючих мікроорганізмів, фізіологічно активних речовин i біологічних засобів захисту рослин: Рекомендації. Київ : Аграрна наука. 2000. 36 с.

9. Тараріко О. Г., Шерстобоєва О. В., Патика В. П. Концепція і наукове обгрунтування основних напрямків удосконалення систем випуску і реалізації мікробіологічних препаратів для сільськогосподарського виробництва. Мікробіологічний журнал. 1997. 59. № 4. С. 102-108.

10. Щербатий О. А., Лепеха О. П. Використання мікроорганізмів для підвищення продуктивності ячменю. Матеріали всеук. наук.прак конф. молодих вчених і спеціалістів. Дніпропетровськ. 2002. C. 32.

11. Нові штами мікроорганізмів для підвищення ефективності землеробства. Розробки виробнищтву. Київ : Аграр. Наука, 1999. С. 98. 
12. Доспехов Б. А. Методика опытного дела. Москва : Колос, 1985. $336 \mathrm{c.}$

13. Погорілько М. А., Граб Т. О., Усманова Т. О., Хаїтова Н. О. Виробництво та застосування біологічних препаратів на основі азотфіксуючих бактерій - необхідна умова оптимізації агроекосистем. Сталий розвиток агроекологічних систем в умовах обмеженого ресурсного забезпечення: Матеріали наук.-метод. конф. Київ. 1998. C. 128-129.

14. Шерстобоева Е. В., Дудинова И. А., Шерстобоев Н. К. Биопрепараты азотфиксирующих бактерий: проблемы и перспективы применения. Мікробіологічний журнал. 1997. Вип. 59, № 4. C. 109-117. 